\title{
RELATIONSHIP BETWEEN PERSONAL SELF-EFFICACY AND FLOOD DISASTER PREPAREDNESS OF INDONESIAN NURSES
}

\author{
Adi Try Wurjatmiko ${ }^{1^{*}}$, Lilik Zuhriyah ${ }^{2}$, Mukhamad Fathoni $^{2}$ \\ ${ }^{1}$ Master's Program of Nursing, Faculty of Medicine, Universitas Brawijaya, Indonesia \\ ${ }^{2}$ Faculty of Medicine, Universitas Brawijaya, Indonesia
}

\author{
Accepted: 17 March 2018 \\ *Correspondence: \\ Adi Try Wurjatmiko \\ Faculty of Medicine, Universitas Brawijaya \\ Jl. Veteran Malang 65145, East Java - Indonesia \\ Email: dhistowurjatmiko@gmail.com
}

Copyright: (C) the author(s), YCAB publisher and Public Health of Indonesia. This is an open-access article distributed under the terms of the Creative Commons Attribution Non-Commercial License, which permits unrestricted non-commercial use, distribution, and reproduction in any medium, provided the original work is properly cited.

\begin{abstract}
Background: Indonesia is one of the countries that is prone to natural disaster. There are between 1,500-2,000 cases of natural disasters annually and most of the cases are related to hydro meteorological activities such as flood. Preparedness is a critical phase in disaster management as it is able to decrease or prevent negative effects of natural disasters for example negative effects of natural disaster in health sector. Nurse preparedness is one of the determining factors in describing how severe effects of natural disasters are in health sector.

Objective: To identify and analyze relationship between personal self-efficacy and flood disaster preparedness of Indonesian nurses.

Method: The study used analytical observational design with cross sectional approach. The population was 191 nurses and the samples were 160 nurses working in public health centers. The sampling method was purposive sampling. The setting on the study was 5 public health services located in areas prone to flood in Kendari, Southeast Sulawesi, Indonesia. Spearman rank correlational test was used for data analysis with significant level $(\alpha)=0.05$.

Results: Spearman Rank correlational test showed a significant relationship between self-efficacy and flood disaster preparedness of nurses $(\mathrm{p}=0.00$ and $\mathrm{r}=0.63)$.

Conclusion: Personal factor such as nurses' self-efficacy in dealing with flood is related to their flood disaster preparedness in Kendari, Southeast Sulawesi, Indonesia.
\end{abstract}

Key words: Self-efficacy, Nurse Preparedness, Flood

\section{BACKGROUND}

Natural disaster is taking place anywhere. It refers to an event that disturbs or worsens quality of life and livelihood of an individual, family and the society. Disaster occurs when threat to certain area is larger than its capacity to overcome the threat (UNSDR, 2014; WHO \& ICN, 2009). Indonesia is one of the countries with very high cases of natural disaster, which is 1,500-2,000 times per year. In 2016, there were 2,342 cases of natural disaster, increasing 35\% than the 2015 natural disaster cases (1.582 cases) (BNPB, 2017). There are approximately five natural disasters taking place for one day in Indonesia.

Kendari is a city in Southeast Sulawesi with high disaster risk index, 148.4. As the result, Kendari ranked the $21^{\text {st }}$ out of 136 cities and municipalities in Indonesia of which disaster risk index is high and therefore is categorized as priority for the 2013-2019 national disaster risk reduction program (BNPB, 2017). Natural 
disasters in Kendari Southeast Sulawesi are dominated by hydro meteorological activities, and $80 \%$ of them are flooding (BPBD Kendari, 2017). Badan Penanggulangan Bencana Daerah (BPBD) or the National Agency for Disaster Management of Kendari stated that geographical condition, Wanggu river overflow and high rainfall are underlying reasons why Kendari is prone to flood. Badan Meteorologi Klimatologi dan Geofisika (BMKG) or Meteorology, Climatology and Geophysics Agency of Kendari predicted 1-2\% increase of rainfall in 2018 and as the consequence, flooding may happen again in Kendari (BMKG Kendari, 2017).

Disaster has tremendous impacts towards human being and environment such as increasing cases of disease, disability, and death, health issues, famine, as well as damage to infrastructure (Kurniayanti, 2012). The 2016 flood in Kendari affected 7,106 people and $57.3 \%$ of them suffered from both physical and psychological health issues. The 2017 flood in the city affected 7,311 people and $59.8 \%$ of them suffered from health issues (BPBD Kendari, 2017).

Sufficient preparedness of related stakeholders such as health workers including nurses in public services would have been able to minimize health issues among the flood victims. International Council of Nurse (ICN) \& World Health Organization (WHO) (2009) explained that preparedness is critical phase in disaster management; inadequate planning will result in greater impact of natural disaster, more suffering condition for natural disaster survival, worse health condition of disaster victim and even increasing death case. Health worker preparedness including nurses plays such important role in preventing disaster victims from suffering from more health issues. Well-prepared nurses will be able to improve the victims' health condition minimizing more death cases (Lowery, Robinson, \& Taylor, 2017). According to $B N P B$ and Indonesian National Department of Public Health, nurses working in public health center have important role in disaster management in Indonesia more importantly in health facilities in smaller areas such as kecamatan and kelurahan.

One of the affecting factors in nurse preparedness in dealing with disaster is personal factor such as self-efficacy. Previous study stated that efficacy can improve nurse preparedness in facing natural disaster. Selfefficacy is significant factor to determine one's behavior and performance including when disaster strikes. Self-efficacy will develop nurse's optimism allowing them to be prepared to face disaster (Melnikov, Itzhaki, \& Kagan, 2014). According to $B N P B$, preparedness level of health workers such as nurses in the center and east part of Indonesia is low, including Kendari, Southeast Sulawesi. Previous study the researchers conducted in the Department of Public Health of Kendari found five public health centers (Puskesmas) located in areas prone to flooding, namely Puskesmas Mata, Puskesmas Poasia, Puskesmas Lepo-lepo, Puskesmas Benu-benua and Puskesmas Kandai. Based on the interview from 10 nurses working in the five public health centers, $60 \%$ of the nurses felt that they were not ready to conduct preparedness program involving the society. The percentage described that the Department of Public Health was facing a challenge to improve the nurse preparedness in overcoming flood in the area, which is related to self-efficacy of the nurses in dealing with disaster.

\section{METHODS}

\section{Study design}

The study used analytical observational design with cross sectional approach.

Setting

The setting of the study was in the Public Health Center of which location was areas prone to flooding in Kendari Southeast Sulawesi, namely Puskesmas Mata, Puskesmas Poasia, Puskesmas Lepo-lepo, Puskesmas Benu-benua and Puskesmas Kandai. The study was conducted on November 6, 2017 to December 6, 2017. 


\section{Research subjects}

The population was 191 nurses working in the public health centers located in areas prone to flooding in Kendari and the number of respondents in the study was 160 nurses. The sampling technique was purposive sampling.

\section{Instrument}

A modified instrument by Ansthobar \& Miellen (2013) was used to determine the nurses' self-efficacy. The instrument has good validity (r-corrected item-total correction $\geq$ 0.3 ) and reliability (Cronbach alpha $=0.913$ ). Self-efficacy was considered good if the score $>62.5 \%$ and poor if the score $\geq 62.5 \%$. While nurse preparedness instrument using concept by the United Nations International Strategy for Disaster Reduction (2014) was modified by researcher to determine nurse preparedness with good validity (r-corrected item-total correction $\geq 0.3$ ) and reliability (Cronbach alpha $=0.902)$. Nurse disaster preparedness was considered good if the score $>62.5 \%$ and poor if the score $\geq 62.5 \%$.

\section{Ethical consideration}

The study was examined and approved by health research ethics committee of Haluoleo University Southeast Sulawesi (Number 1922/UN29.20/PPM/2017).

\section{Data analysis}

There were two types of analyses, univariate and bivariate. Univariate analysis was conducted to identify characteristics of the respondents, while bivariate analysis was conducted to describe relationship between self efficacy and nurse preparedness during flood using Spearman Rank correlation test with significant level $(\alpha)=0.05$.

\section{RESULTS}

Table 1, 2 and 3 described the result of the univariate analysis. It explained the characteristics of the respondents, age, length of work, level of education, disaster training experience and disaster training source.

Table 1 Respondents' characteristics based on age and length of work

\begin{tabular}{lcccc}
\hline Respondents' Characteristics & N & Minimum & Maximum & Mean \\
\hline Age (Year) & 160 & 23 & 51 & 32.5 \\
Length of Work (Year) & 160 & 2 & 21 & 7.7 \\
\hline
\end{tabular}

Table 2 Respondents' characteristics based on sex, level of education, disaster training experience and disaster training source

\begin{tabular}{lcc}
\hline Respondents' Characteristics & Frequency (n) & Percentage (\%) \\
\hline Sex & & \\
Female & 116 & 72.5 \\
Male & 44 & 27.5 \\
Total & 160 & 100.0 \\
\hline Education & 90 & \\
Three-Year Program & 7 & 56.2 \\
Four-Year Program & 32 & 4.4 \\
Bachelor Degree & 31 & 20.0 \\
Ners & 160 & 19.4 \\
Total & & 100.0 \\
\hline Disaster Training Experience & 42 & \\
Yes & 118 & 26.2 \\
No & 160 & 73.8 \\
Total & & 100.0 \\
\hline
\end{tabular}


Based on Table 1, it was found that average age of the respondents was 32.5 years old. The youngest respondent was 23 years old while the oldest one was 51 years old. Average length of work of the respondents was 7.7 years. The shortest was 2 year of work and the longest was 21 years of work.

From Table 2, most of the respondents were female (116 respondents or $72.5 \%$ ), graduated from a three-year nursing education (90 respondents or 56.2\%), and had never participated in any disaster training (118 respondents or $73.8 \%$ ).

While Table 3 described that 90 respondents $(56.2 \%)$ had poor self-efficacy and 108 respondents $(67.5 \%)$ had poor preparedness when flood struck.

Table 3 Respondents' distribution based on self-efficacy and nurse preparedness of flood disaster

\begin{tabular}{lccc}
\hline Variable & $\begin{array}{c}\text { Objective } \\
\text { Criteria }\end{array}$ & Frequency (f) & Percentage (\%) \\
\hline Self-Efficacy & Poor & 90 & 56.2 \\
& Good & 70 & 43.8 \\
& Total & 160 & 100 \\
\hline Nurse Preparedness & Poor & 108 & 67.5 \\
& Good & 52 & 32.5 \\
& Total & 160 & 100 \\
\hline
\end{tabular}

Table 4 Spearman correlational test bivariate analysis result between self-efficacy and flood disaster preparedness of nurses in Kendari Southeast Sulawesi

\begin{tabular}{lcc}
\hline Variable & \multicolumn{2}{c}{ Nurse Preparedness } \\
\hline \multirow{3}{*}{ Nurse's Self Efficacy } & Correlation Coefficient $(\mathrm{r})$ & 0.63 \\
\cline { 2 - 3 } & Sig. (2-tailed) $(\mathrm{p})$ & 0.00 \\
\cline { 2 - 3 } & $\mathrm{N}$ & 160 \\
\hline
\end{tabular}

Table 4 showed that p-value $0-00 \quad(<0.05)$, which indicated that there was significant correlation between the self-efficacy and nurse preparedness during flood in Kendari, Southeast Sulawesi. The degree of relationship was 0.63 , which considered significant and positive.

\section{DISCUSSION}

Self-efficacy refers to personal belief that encourages positive behavior through an action, activity or task. Self-efficacy also means personal belief related to ability someone has to carry out responsibility given to him or her based on his or her role and functions.

The bivariate analysis shows significant relationship between self-efficacy and flood disaster preparedness of nurses in Kendari, Southeast Sulawesi, which is indicated by $\mathrm{p}$ value of $0.00(<0.05)$. The finding is in line with previous study that self-efficacy is one of the factors that influences nurse preparedness when disaster strikes (Ansthobar. D \& Miellen. C, 2013).

In disaster preparedness, self-efficacy determines individual independence in planning and preparing himself or herself to face disaster. Self-efficacy is one of deciding factors that determine how well or poor nurse preparedness for disaster. Having good selfefficacy, nurse will be motivated and feel some responsibility to conduct activities of which goal is minimizing effects of natural disaster (Melnikov et al., 2014). Alwilsol argued that self-efficacy is proportional to nurse preparedness in facing and overcoming effects of natural disasters, which meant when nurses 
had good self efficacy in facing natural disaster, they would have better preparedness when disaster strikes and at the opposite, when nurses had poor self-efficacy, they would have less preparation when disaster happened (Alwisol, 2004). It is in line with the result of the univariate analysis that most of the nurses working in Public Health Center in Kendari had low self-efficacy $(56.2 \%)$ and at the same time, their preparedness in facing flood was also low $(67.5 \%)$.

Self-efficacy refers to personal or individual factor creating strong motivation for nurses to make preparations when disaster strikes based on their roles and function in certain working team (Samuel, Griffin, White, \& Fitzpatrick, 2015). Study stated that motivation to participate in activities to minimize effects of disaster developed by self-efficacy would last longer, in which nurses would always feel optimistic and resilient when they encountered difficulties while preparing such activities (Devon Berry PhD, 2012). It is stated that individual self-efficacy was influenced by several factors such as mastery experiences, vicarious experiences, social persuasion, as well as physiological and emotional states. On the other hand, Ansthobar \& Miellen (2013) postulated that nurse's self-efficacy is affected by disaster training experience, sex, level of education and working culture in institution where he or she is working.

Participation in disaster training is one of the factors affecting nurse's self-efficacy during natural disaster. The training provides information on what nurses should prepare or do when disaster strikes and as the result, the nurses are certain that they are able to help minimizing effects of natural disaster. On the other hand, nurses who have never participated in such training will be confused, uncertain and disoriented (Melnikov et al., 2014). It is in line with the result of the univariate analysis that $73.8 \%$ of the nurses had never participated in any disaster relief program, and as the consequence that $67.5 \%$ of them had low preparedness in facing disaster.
Ansthobar \& Miellen (2013) explained that sex was another factor affecting nurse self-efficacy in conducting disaster preparation program. It is in line with another study that female had better self-efficacy in running her task and responsibility than male (Feist \& Feist, 2010). The statement is at the opposite of the finding of the study. The finding revealed that $72.5 \%$ of the nurses in public health centers located in the areas prone to flooding in Kendari, Southeast Sulawesi were female, yet $56.2 \%$ of them had low self-efficacy related to disaster preparedness.

Level of education has a contribution in developing self-efficacy of nurses while they are preparing for natural disaster (Melnikov et al., 2014). Nurses with high level of education would have more complex knowledge on disaster management or disaster preparedness making them able to make quick and accurate decision on which programs or treatment public needed when disaster struck. Such condition allows nurses to become more confident in making preparation that will minimize effects of natural disaster. The univariate analysis revealed that $56.2 \%$ of the nurses in Kendari Southeast Sulawesi who became the samples graduated from a threeyear nursing education and only $20 \%$ of them graduated from a bachelor in nursing.

Besides participation in disaster relief training, sex and level of education, value and culture are other factors affect nurse's self-efficacy in conducting disaster preparedness program (Ansthobar. D \& Miellen. C, 2013). It is in line with Melnikov, et.al. (2014) that value, culture and tradition in places where nurse was working were strongly related to his or her level of self-efficacy in disaster preparation. Majority of people in Kendari believe in "pombadoa" in which making preparation for natural disaster may actually cause natural disaster to strike (Mukhlis, 2011). It causes lack of self-efficacy of the nurses to conduct disaster preparation program more particularly one involving the society such as disaster preparedness seminar, training, simulation and early-warning. 
Majority of people in Kendari are members of Tolaki ethnic group that has Mekombulu and Mepokoaso, which literally means deliberation and cooperation. These traditions may help the society preparing for natural disaster. Mekombulu is tradition of the Tolaki ethnic group in which people discuss various issues members of tribe encounter, including natural disaster that happens frequently in their area. This tradition is conducted frequently by various community groups in Kendari, Southeast Sulawesi. On the other hand, Mepokoaso is mutual cooperation and helping each other for example contacting health workers when one of the members of the society is ill, accompanying sick person to public health center or hospital, helping neighbors building their houses, making preparation prior to flood and helping each other when disaster (flood) strikes (Mukhlis, 2011). It is expected that these local wisdom, Mekombulu dan Mepokoaso, encourage nurses in public health centers in Kendari, Southeast to have better self-efficacy related to flood disaster preparedness.

\section{CONCLUSION}

There is significant correlation between the nurses' self efficacy and their flood disaster preparedness in Kendari, Southeast Sulawesi. The degree of the correlation was positive, which indicated that the higher the nurse's self-efficacy, the more preparation they would have for flood disaster. From this study, it is expected that nurses should improve their selfefficacy and use local wisdom such as Mekombulu and Mepokoaso tradition from Kendari, Southeast Sulawesi as an instrument to develop nurse self-efficacy. Besides, the Department of Public Health should issue policies that develop nurse preparedness in dealing with natural disaster related to the local wisdom. Future study is needed to focus on how much the local wisdom in Kendari affect nurses' self-efficacy and their preparedness for natural disaster.

\section{REFERENCES}

Alwisol. (2004). Psikologi Kepribadian. Malang: Universitas Muhammyadiah Malang Press.

Ansthobar. D, \& Miellen. C. (2013). Disaster Nursing Management: Janpoor Company.

BMKG Kendari. (2017). Data Curah Hujan Kota Kendari 2016-2017: Badan Meteorologi Klimatologi dan Geofisika (BMKG) Kota Kendari.

BNPB. (2017). Data Informasi Bencana Indonesia. Retrieved 12 September, 2017, from http://dibi.bnpb.go.id/dibi/

BPBD Kendari. (2017). Dokumen Kajian Risiko Bencana Kota Kendari Retrieved 12 September, 2017, from http://bpbd.kendarikota.go.id/

Devon Berry PhD, R. N. (2012). Who will show up? Estimating ability and willingness of essential hospital personnel to report to work in response to a disaster. Online Journal of Issues in Nursing, 17(2), J1.

Feist, J., \& Feist, G. J. (2010). Teori kepribadian. Jakarta: Salemba Humanika.

Kurniayanti, M. A. (2012). Peran Tenaga Kesehatan dalam Penanganan Bencana. Jurnal Ilmiah Kesehatan Media Husada, 1(1), 85-92.

Lowery, R., Robinson, C., \& Taylor, M. (2017). Readiness Near and Far: Regional Hospital Emergency Preparedness During the 2016 Republican National Convention. Journal of Emergency Nursing, 43(3), 284-288.

Melnikov, S., Itzhaki, M., \& Kagan, I. (2014). Israeli nurses' intention to report for work in an emergency or disaster. Journal of Nursing Scholarship, 46(2), 134-142.

Mukhlis. (2011). Pelayanan Publik dan Kearifan Lokal Suku Tolaki Kota Kendari. Kendari: Mitra Jaya.

Samuel, P., Griffin, M. T. Q., White, M., \& Fitzpatrick, J. J. (2015). Crisis leadership efficacy of nurse practitioners. The Journal for Nurse Practitioners, 11(9), 862-868.

UNSDR. (2014). Terminology on Disaster Risk Reduction. Switzerland. Geneva: United Nations International Strategy for Disaster Reduction

WHO, \& ICN. (2009). ICN framework of disaster nursing competencies. The Southeast Asian Journal of Tropical Medicine and Public Health, 40, 57-70.

Cite this article as: Wurjatmiko, A. T., Zuhriyah, L., Fathoni, M. (2018). Relationship between personal self-efficacy and flood disaster preparedness of Indonesian nurses. Public Health of Indonesia, 4(1):25-30. 